University of Nebraska - Lincoln

DigitalCommons@University of Nebraska - Lincoln

Papers in the Earth and Atmospheric Sciences

Earth and Atmospheric Sciences, Department

2003

\title{
Long-Lived Pluvial Episodes during Deposition of the Navajo Sandstone
}

David B. Loope

University of Nebraska, Lincoln, dloope1@unl.edu

Clinton M. Rowe

University of Nebraska, Lincoln, crowe1@unl.edu

Follow this and additional works at: https://digitalcommons.unl.edu/geosciencefacpub

Part of the Earth Sciences Commons

Loope, David B. and Rowe, Clinton M., "Long-Lived Pluvial Episodes during Deposition of the Navajo Sandstone" (2003). Papers in the Earth and Atmospheric Sciences. 211.

https://digitalcommons.unl.edu/geosciencefacpub/211

This Article is brought to you for free and open access by the Earth and Atmospheric Sciences, Department of at DigitalCommons@University of Nebraska - Lincoln. It has been accepted for inclusion in Papers in the Earth and Atmospheric Sciences by an authorized administrator of DigitalCommons@University of Nebraska - Lincoln. 


\title{
GEOLOGICAL NOTES
}

\section{Long-Lived Pluvial Episodes during Deposition of the Navajo Sandstone}

\author{
David B. Loope and Clinton M. Rowe \\ Department of Geosciences, University of Nebraska, Lincoln, Nebraska 68588-0340, U.S.A. \\ (e-mail: dloope1@unl.edu)
}

\begin{abstract}
A B S T R A C T
The Navajo Sandstone of the American Southwest was deposited at approximately 190 Ma in a giant, subtropical dune field near the western margin of Pangea. From this unit, we report thick intervals of dune cross-strata that were churned by insects and trampled by reptiles. Although dunes continued to migrate freely, the distribution of trace fossils shows that plant life in wet interdune areas sustained high levels of animal activity on the dunes for many thousands of years. We interpret this suite of structures as the record of a pluvial episode climatologically similar to the period of "greening" in the Sahara 4000-10,000 yr ago. A high percentage of the rainfall on the Navajo erg recharged the water table and led to the development of highly dilute, local groundwater flow systems that discharged into interdune areas.
\end{abstract}

\section{Introduction}

The lower Jurassic Navajo Sandstone reaches a thickness of nearly $700 \mathrm{~m}$ in southwestern Utah and, with the correlative Aztec and Nugget Sandstones, extends over about $350,000 \mathrm{~km}^{2}$ of the western United States (Kocurek and Dott 1983; fig. 1). The Navajo Sandstone is nearly devoid of animal and plant remains; known vertebrate and plant fossils are mainly associated with rare, thin carbonate lenses, interpreted as interdune ponds (Gilland 1979; Winkler et al. 1991; Bromley 1992). These fossils and evidence of dinosaur tracks at several localities have led some workers to conclude that the Navajo Desert was not entirely hostile to life and that the fossils could be explained either by locally mesic environments within an active sand sea or by periods of wetter climate accompanied by dune stabilization (Winkler et al. 1991; Lockley and Hunt 1995). Marzolf (1983) noted that carbonate lenses and other indicators of a high water table are restricted to the lower Navajo Sandstone, and he argued that fluvial inputs at the southern edge of the sand sea were the source of the water.

Near the Arizona-Utah border (fig. 1), thick slump masses produced by rainfall events that sat-

Manuscript received April 4, 2002; accepted July 22, 2002. urated up to $40 \mathrm{~cm}$ of sand beneath dune slopes are locally present within large-scale dune cross-strata (Loope et al. 2001). Because these slumps are preferentially developed within certain parts of meterscale, annual depositional cycles (Hunter and Rubin 1983; Chan and Archer 1999), Loope et al. (2001) were able to relate them to an annual monsoonal pattern of precipitation. Twenty-four of these slumps appear within one interval that represents $36 \mathrm{yr}$ of dune migration (Loope et al. 2001). In this article, we argue that, in addition to the individual heavy rainfall events recorded by the slumps, these same outcrops record millennialscale intervals of enhanced monsoonal rainfall that periodically gave rise to thriving, interdune-based ecosystems.

\section{Burrows and Bioturbated Sandstones}

Two thick, heavily bioturbated zones occur within erg deposits of the Navajo Sandstone at Coyote Buttes on the Arizona-Utah border ( $C B$ : fig. 1; zones 1 and 2: fig. 2). Bioturbated zone 2 has been traced over approximately $115 \mathrm{~km}^{2}$, but zone 1 appears to be much less extensive (fig. 1). Individual burrows

[The Journal of Geology, 2003, volume 111, p. 223-232] @ 2003 by The University of Chicago. All rights reserved. 0022-1376/2003/11102-0006 \$15.00 


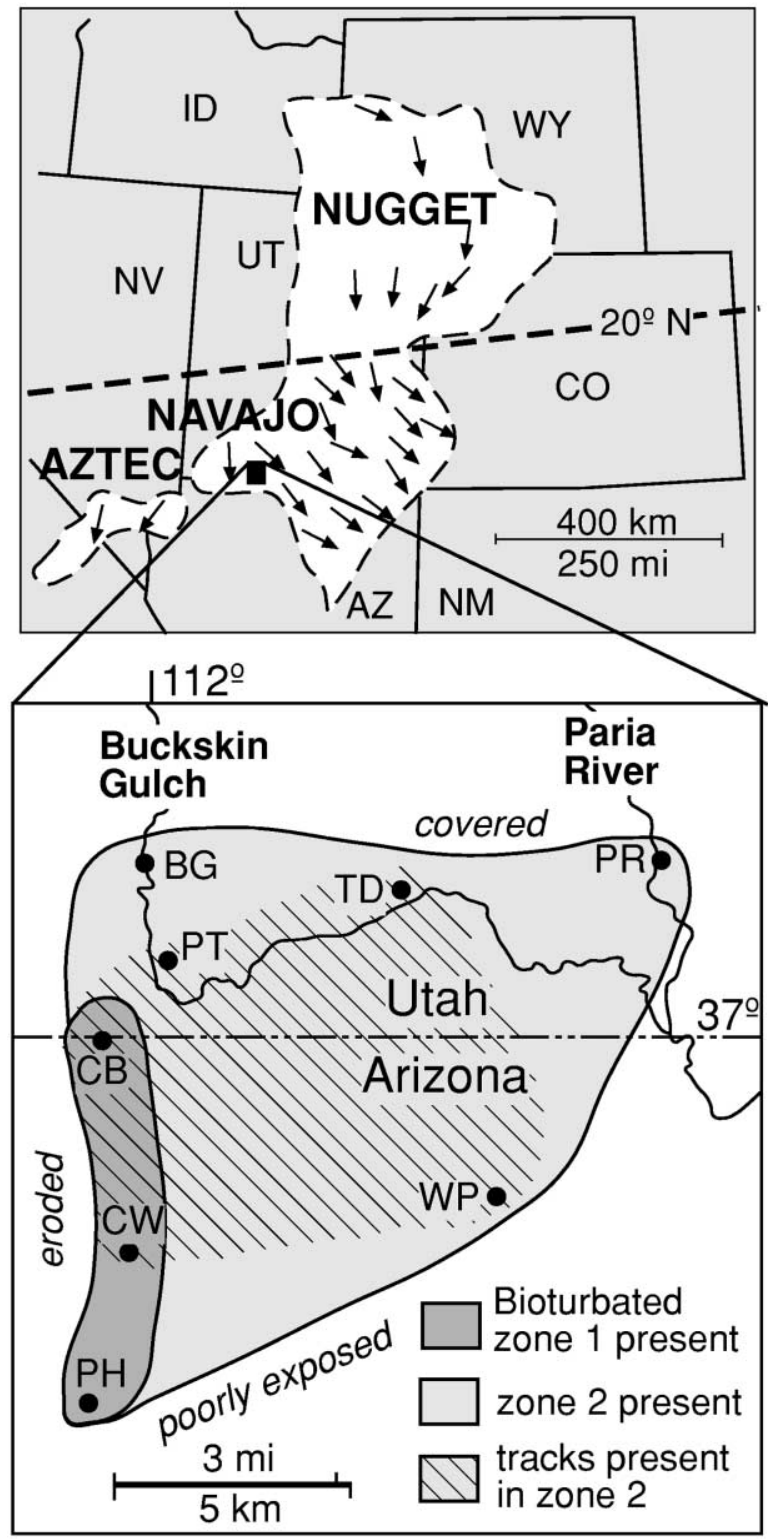

Figure 1. Extent of the Navajo-Nugget-Aztec sand sea in the western United States and location of study area. Arrows show mean paleowind vectors (modified from Kocurek and Dott 1983; paleolatitude from Peterson 1988). Study localities: $B G$, Buckskin Gulch $\left(37^{\circ} 02^{\prime} 00.3^{\prime \prime} \mathrm{N}, \quad 112^{\circ} 00^{\prime} 04.7^{\prime \prime} \mathrm{W}\right) ; \quad C B$, Coyote Buttes (36 $\left.59^{\prime} 57.6^{\prime \prime} \mathrm{N}, 112^{\circ} 00^{\prime} 34.6^{\prime \prime} \mathrm{W}\right) ; C W$, Cottonwood Cove $\left(36^{\circ} 57^{\prime} 15.3^{\prime \prime} \mathrm{N}, 112^{\circ} 00^{\prime} 19.5^{\prime \prime} \mathrm{W}\right) ; \quad P H$, Paw Hole $\left(36^{\circ} 55^{\prime} 49.9^{\prime \prime} \mathrm{N}, 112^{\circ} 00^{\prime} 38.8^{\prime \prime} \mathrm{W}\right) ; \quad P R$, Paria River $\quad\left(37^{\circ} 02^{\prime} 09.6^{\prime \prime} \mathrm{N}, \quad 111^{\circ} 52^{\prime} 03.5^{\prime \prime} \mathrm{W}\right) ; \quad P T$, Point $\left(37^{\circ} 00^{\prime} 47.9^{\prime \prime} \mathrm{N}, \quad 111^{\circ} 59^{\prime} 36.1^{\prime \prime} \mathrm{W}\right) ; \quad T D, \quad$ The Dive $\left(37^{\circ} 01^{\prime} 53.5^{\prime \prime} \mathrm{N}, 111^{\circ} 55^{\prime} 31.4^{\prime \prime} \mathrm{W}\right)$; and $W P$, White Pocket $\left(36^{\circ} 57^{\prime} 26.8^{\prime \prime} \mathrm{N}, 111^{\circ} 53^{\prime} 58.9^{\prime \prime} \mathrm{W}\right)$. The lateral continuity of bioturbated zones 1 and 2 and of vertebrate tracks in zone 2 (fig. 2) is indicated by their presence/absence at the study localities. are unlined and appear as both concave and convex epireliefs (fig. 3a). Burrows are about $5 \mathrm{~mm}$ in diameter and lie both parallel to and at high angles to stratification. Although burrows are common within grain-flow (avalanche) strata, they are much more distinct where they disrupt the thin, inversegraded laminae produced by climbing wind ripples. Rock surfaces displaying more than 1000 burrows/ $\mathrm{m}^{2}$ are widespread within those parts of zones 1 and 2 that are not completely bioturbated (sensu Droser and Bottjer 1989). Burrows are commonly clustered in groups of 20-40 (fig. 3b), and vertical shafts sometimes appear in double parallel rows. We interpret the burrow clusters not as feeding traces but as emergence tunnels made by insects or arachnids that developed within multicelled nests dug and provisioned by individual females. On the basis of the diameter and clustering of the Jurassic burrows and their presence within largescale eolian cross-strata, the morphology and general natural history of the trace makers may have been similar to those of modern digger wasps and sand treader crickets (Ahlbrandt et al. 1978). Colonies of digger wasps are present in nearly every dune field in North America (Evans 1957), and their traces have been identified in Quaternary dune deposits of the Bahamas (Curran and White 2001). The burrows lying parallel to or at low angles to bedding in the Navajo Sandstone may represent tunnels dug by females during nesting or the "sleeping" burrows made by both males and females to escape the heat of midday or to spend the night (Evans 1957). Evans (pers. comm., 2002) notes, however, that wasps prefer to dig on the stoss (erosional) sides of modern dunes, while crickets burrow on both stoss and lee slopes. Crickets (Orthoptera) are known from the Paleozoic, but digger wasps (Hymenoptera) do not have a body fossil record older than the Eocene (Evans 1966, p. 393). Traces attributed to these wasps have been found recently, however, in the upper Triassic Chinle Formation (Hasiotis et al. 1995; Hasiotis 1998).

Sharp contacts between trough cross-strata above and below the bioturbated zones were produced by the migration of sinuous-crested dunes into dry, erosional interdunes. Within the bioturbated zones, however, thick interdune sandstones are present (fig. 2). These interdune deposits are heavily burrowed, but vestiges of decimeter-scale, horizontal bedding are apparent. Subaqueously deposited, small-scale trough cross-strata and thin mud curls are locally developed. Interdune deposits extend as much as $600 \mathrm{~m}$ before pinching out against subjacent bioturbated sandstone. Carbonate lenses are absent from our study site. No direct evidence of 


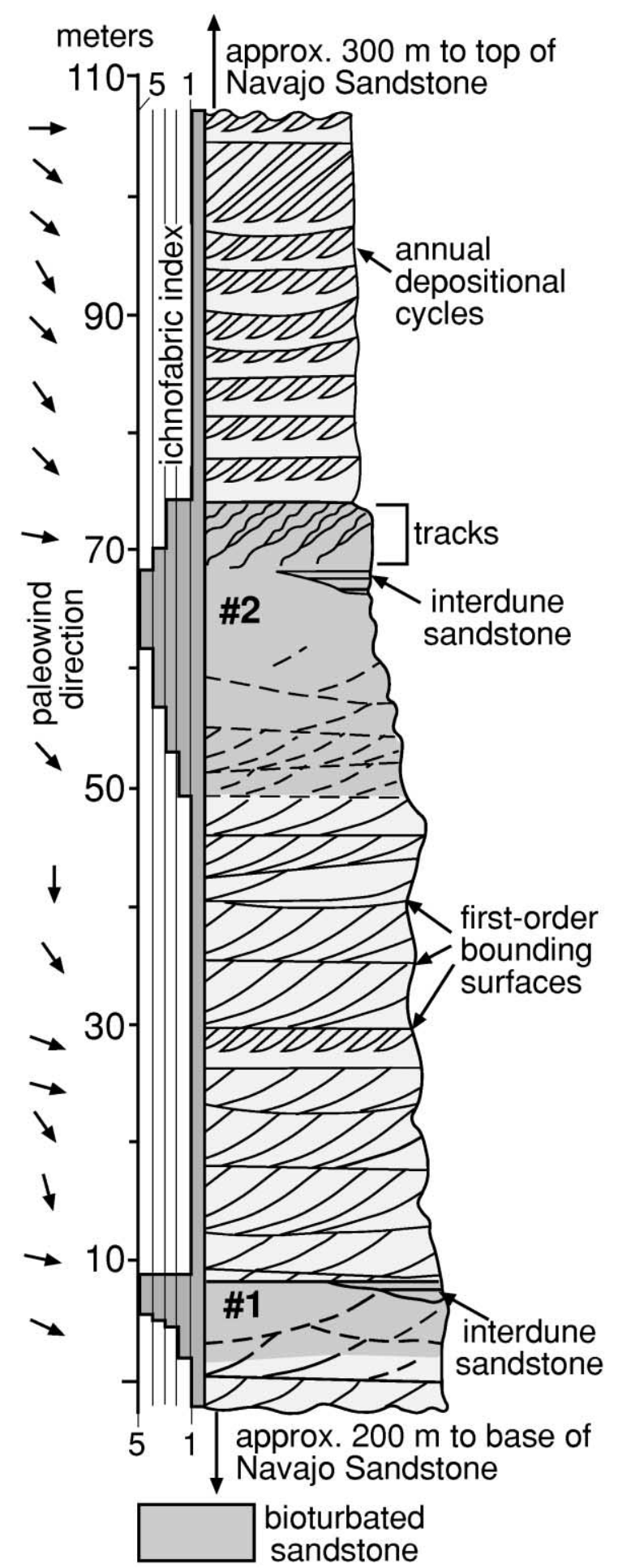

Figure 2. Stratigraphic section at Coyote Buttes $(C B$ : fig. 1) showing distribution of burrows and tracks in the Navajo Sandstone. Ichnofabric index (Droser and Bottjer 1989) ranges from 1 (no bioturbation) to 5 (complete bioturbation). The dip directions of cross-strata show that the dominant, northwesterly wind direction did not change during deposition of the studied interval. plant life is preserved in either dune or interdune deposits, but the evidence of intermittent flooding of the interdunes along with the abundant animal traces in both dunes and interdunes strongly suggest that bacterial mats or rooted plants were present in interdune areas.

\section{Reptile Tracks}

Within the upper part of bioturbated zone 2, hundreds of reptile tracks are seen in plan view on numerous angle-of-repose slopes (fig. 4a, 4b). Tracks exposed in vertical cross section (fig. $4 c$ ) are visible within large volumes of rock: one 7-m-thick set of trampled cross-strata is exposed along strike for more than $400 \mathrm{~m}$; another set, exposed in dipparallel section, records continuous trampling during $160 \mathrm{~m}$ of dune migration. The trampled strata have been traced over about $65 \mathrm{~km}^{2}$ (fig. 1). Burrowed and trampled strata are locally truncated by deep scours filled by large-scale eolian trough crossstrata that lack both burrows and tracks.

Tracks are attributable to Brasilichnium (made by a nonmammalian synapsid; Leonardi 1981; Lockley and Hunt 1995; fig. 4a) and Grallator (made by a small theropod dinosaur; Lockley and Hunt 1995; fig. 4b). Orientations of individual tracks and of trackways with up to 15 individual tracks show that animals moved up, down, and along the dune face. There are no tension cracks or breccias associated with tracks, which suggests that they were made in dry sand. Tracks in grainflow (avalanche) deposits are about as deep as they are wide; tracks made in thin sets of ripple laminae underlain by grain flows are shallower. Tracks can seldom be discerned in thick wind-ripple strata, presumably because these deposits were tightly packed and firm compared with grain flows. Tracks are distributed throughout the grain-flowdominated portion of the annual depositional cycles and along the contacts between successive cycles, which suggests that animals were active in the dune field throughout the year.

\section{Implications for Paleoenvironment}

Paleohydrogeology. On the basis of soft-sediment slumps enclosed within single sets of cross-strata, Loope et al. (2001) argued that monsoon rains fell annually on some of the large Navajo dunes and that individual storms may have delivered as much as $170 \mathrm{~mm}$ of rain. In the sand seas of modern Saudi Arabia, if dunes are unvegetated and relatively 

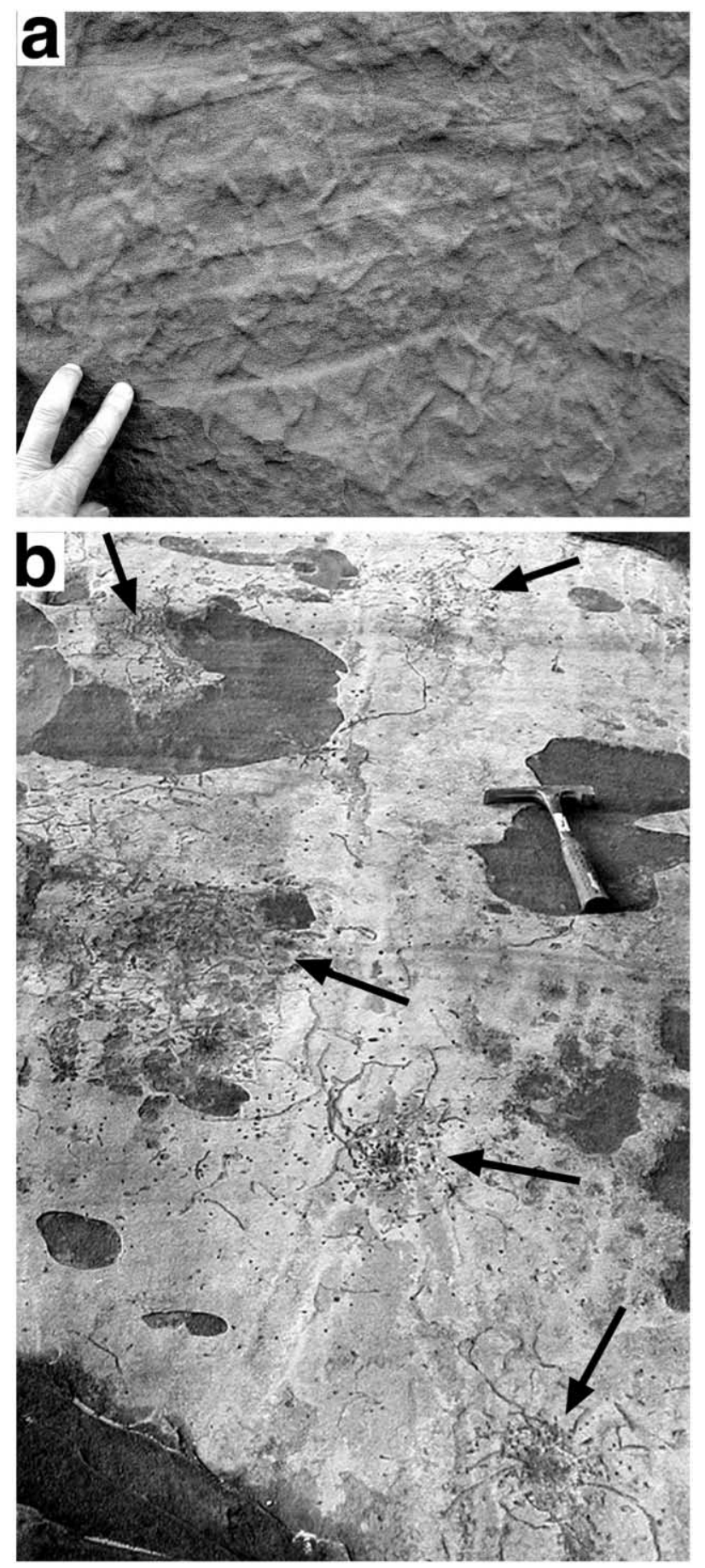

Figure 3. Burrows within cross-strata of the Navajo Sandstone. $a$, Closely spaced burrows preserved as convex epireliefs (ichnofabric index $=3$ ) within wind-ripple strata exposed on a vertical cliff face. $b$, Clusters of burrows interpreted to be the result of emergence of a new generation of insects from a multicelled nest. coarse grained, recharge of rainwater to the groundwater reservoir takes place even under hyperarid conditions (Dincer et al. 1974). The Selima Oasis in northwest Sudan receives $<1 \mathrm{~mm}$ of rain per year today, but during the mid-Holocene pluvial episode, precipitation may have reached $200 \mathrm{~mm} / \mathrm{yr}$ (Haynes 1987). If a climate change of similar magnitude took place in the Navajo Desert and only half of the rainfall recharged the water table below the dunes, the water table would have risen 250 $\mathrm{mm} / \mathrm{yr}$ (assuming $40 \%$ porosity). If this substantial rate of recharge was sustained for a few decades, groundwater would have risen under the Jurassic dunes and discharged into interdunes. The movement of shallow groundwater in this situation would have been dominated by local flow cells (Toth 1963; Winter 1976) rather than by the intermediate- or regional-scale flow systems of hyperarid regimes (where the water table is far below the interdune surfaces; fig. 5).

Because the flow paths and transit times were short, the water emerging at the great majority of interdune surfaces during the Jurassic pluvial episodes was probably highly dilute. The absence of carbonate beds at our study site suggests that, during the pluvial intervals, this part of the erg was dominated by groundwater recharge rather than discharge. For this reason, we argue that the primary clue to the presence of fresh surface water (and pluvial conditions) in ancient ergs is not chemical precipitates but trace fossils. Like the carbonate facies within the "fossil oases" described by Smith and Mason (1998, p. 547) from the Tertiary deposits of the Namib Desert, the carbonate lenses found within the Navajo Sandstone at other sites (Gilland 1979; Winkler et al. 1991; Bromley 1992) probably were formed from solutes delivered by fluvial systems and by the discharge from regionalscale groundwater flow systems.

Life in the Dune Field. Within some strongly bioturbated cross-strata, it is possible to discern annual depositional cycles (Hunter and Rubin 1983; fig. 6a) and rain-induced slump masses (Loope et al. 2001; fig. 6b). Although the set of cross-strata containing 24 monsoon-related slump masses described by Loope et al. (2001; their fig. 5 and supp. info.) exhibits no burrows, it lies directly above the intensely bioturbated cross-strata of zone 2 (fig. 2). From this, we infer that the series of slump events described by Loope et al. (2001) took place after interdune environments capable of sustaining large animal populations had disappeared. Although the annual pattern of heavy rainfall events persisted, these rains were apparently insufficient to maintain interdune plant life. 

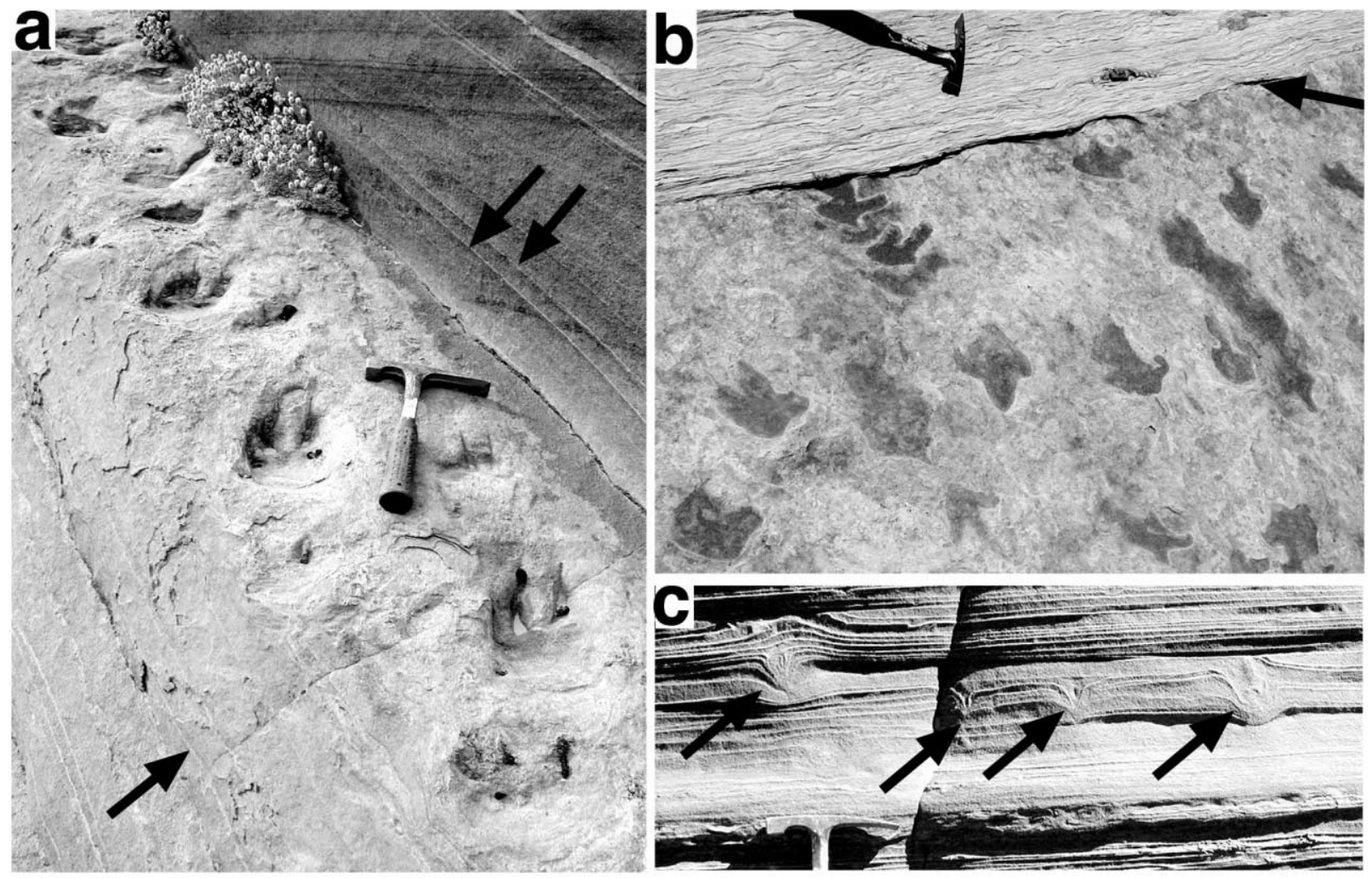

Figure 4. Reptile tracks within grain-flow (avalanche) cross-strata of the Navajo Sandstone (CB: fig. 1). $a$, Upslopedirected trackway of a synapsid (Brasilichnium); arrows mark pin stripes between grain-flow tongues (Loope et al. 2001). b, Numerous tracks made $7 \mathrm{~m}$ above the toe of the slope by theropod dinosaurs (Grallator). Overlying set (above arrow) is devoid of traces and apparently postdates pluvial episode. $c$, Vertebrate tracks in cross section (arrows). Hammerhead for scale at bottom of photo. View is down dip; deformation is recorded by pin stripes between grainflow tongues. Tracks are deep because grain-flow tongues are loosely packed.

The 160-m-long exposure of a single set of crossstrata that contains tracks, burrows, and annual depositional cycles and lies parallel to the paleowind direction demonstrates that animals were active year-round at the site for at least $100 \mathrm{yr}$. The record of tracks and shallow burrows is unbroken by barren cross-strata. The continuity of this record is consistent with a hydrologic regime in which runoff was almost nil and recharge was very high. The effect of short-term droughts on animals and plants was damped by the slow, steady flow from the groundwater mounds beneath the dunes to the interdunes.

The fact that large volumes of sand were bioturbated by shallow burrowers suggests that dunes were in constant migration, an idea supported by the lack of direct evidence that the Jurassic dunes became stabilized. If plants had grown on the dunes, they would have slowed dune migration and modified airflow patterns on the lee face and thus would have affected the deposition of sediment. Within bioturbated cross-strata, the thickness, geometry, and distribution of grain-flow and windripple strata within annual depositional cycles are quite similar to those in sets that lack burrows, which suggests that dunes remained unvegetated during pluvial episodes. But because most insects have small home ranges, plant life and primary consumers (the invertebrate prey of wasps) must have been abundant and widespread in interdune environments.

Erosion of stabilized dunes by heavy rainfall events and deposition in adjacent interdunes has been studied in subtropical Africa and the Great Plains of North America (Talbot and Williams 1978; Sweeney and Loope 2001). Some of the interdune deposits could have resulted from erosion of surrounding dunes during rainstorms, but the question of dune stabilization remains equivocal. 

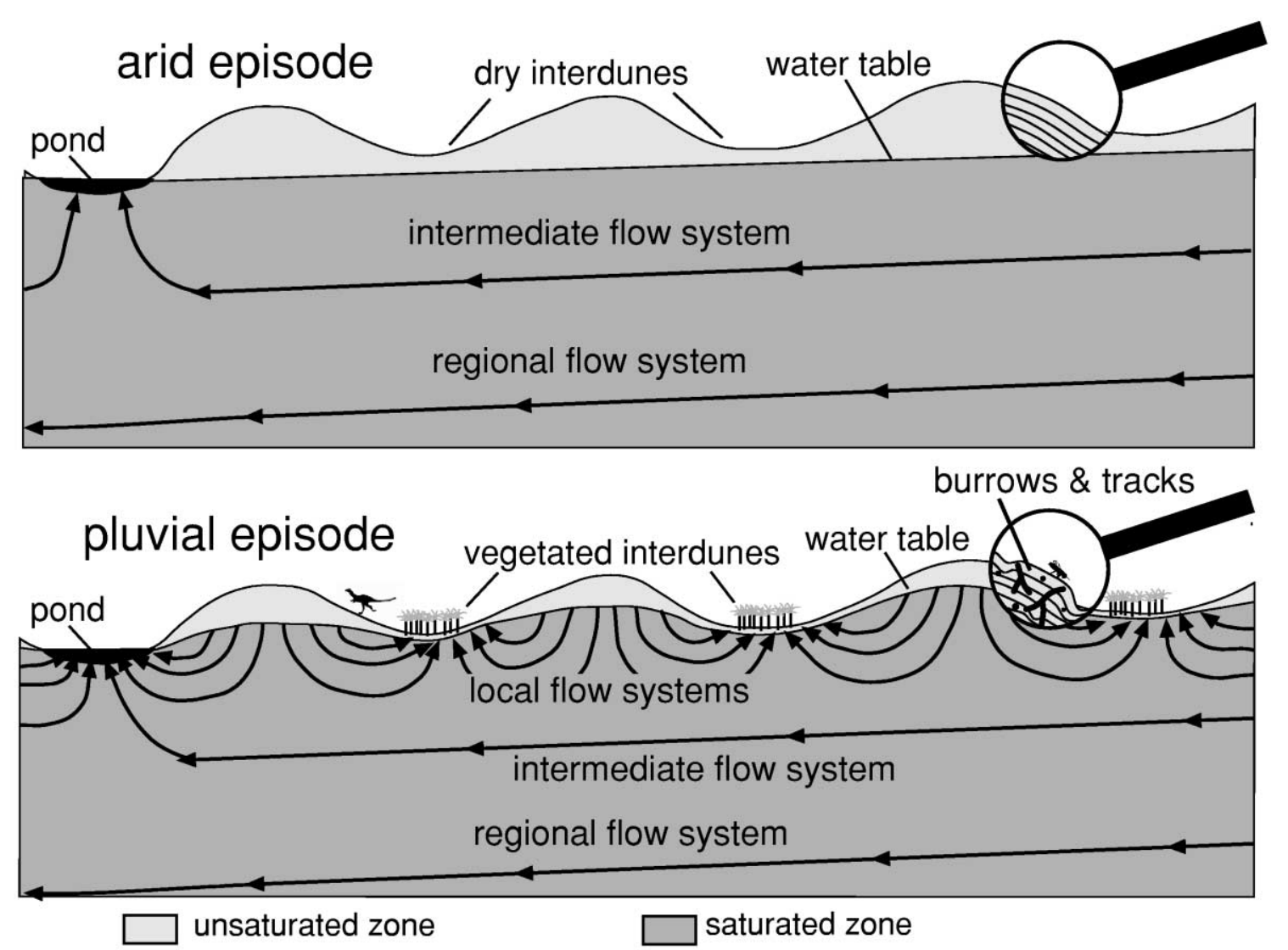

Figure 5. Hypothesized changes in hydrologic regime during deposition of the Navajo Sandstone. During arid intervals, the water table is nearly flat, and sites of discharge are widely spaced; carbonates accumulate in rare, widely spaced ponds. During pluvial intervals, the water table rises and becomes mounded beneath dunes. Water discharges in interdunes and supports algal mats or rooted plants, insects, and reptiles. Precipitates do not form because water is highly dilute and is recharging regional aquifer.

\section{Pluvial Episodes}

The strata shown in figure 2 can be interpreted in two ways: (1) the burrowed zones represent two distinct pluvial episodes or (2) the two burrowed zones developed during a single pluvial episode and became superimposed by the climb of compound bedforms or draa (Brookfield 1977). Interpreting the 60-m-thick coset of cross-strata between the interdune deposits in fig. 2 as having been deposited by a single compound bedform could explain the absence of wet interdune deposits between the individual sets of burrowed cross-strata (fig. 7). Because only two bioturbated zones are superimposed, if the "climbing compound bedform" hypothesis (fig. 7) is correct, the pluvial episode recorded by the burrowed and trampled zones lasted only long enough for the giant bedforms to migrate one wavelength. It follows that the bioturbated zones should not extend more than $2-3 \mathrm{~km}$ in a direction parallel to the paleowind.

Several observations, however, strongly undermine the climbing compound bedform hypothesis and indicate that the two zones of bioturbated strata accumulated during two distinct pluvial episodes. The lateral continuity of zone 2 parallel to the paleowind direction (at least $10 \mathrm{~km}$; fig. 1) is much greater than that of zone 1 and is inconsistent with this model. Also, vertebrate tracks are abundant in zone 2 but are absent from zone 1 . This difference is hard to explain if the strata accumulated synchronously in adjacent interdunes. Further, the climbing compound bedform hypothesis requires that all strata between the wet interdune deposits were deposited by a single large bedform. The bounding surfaces between most of the sets of cross-strata in this interval, however, are parallel to the interdune strata and thus must be interpreted 


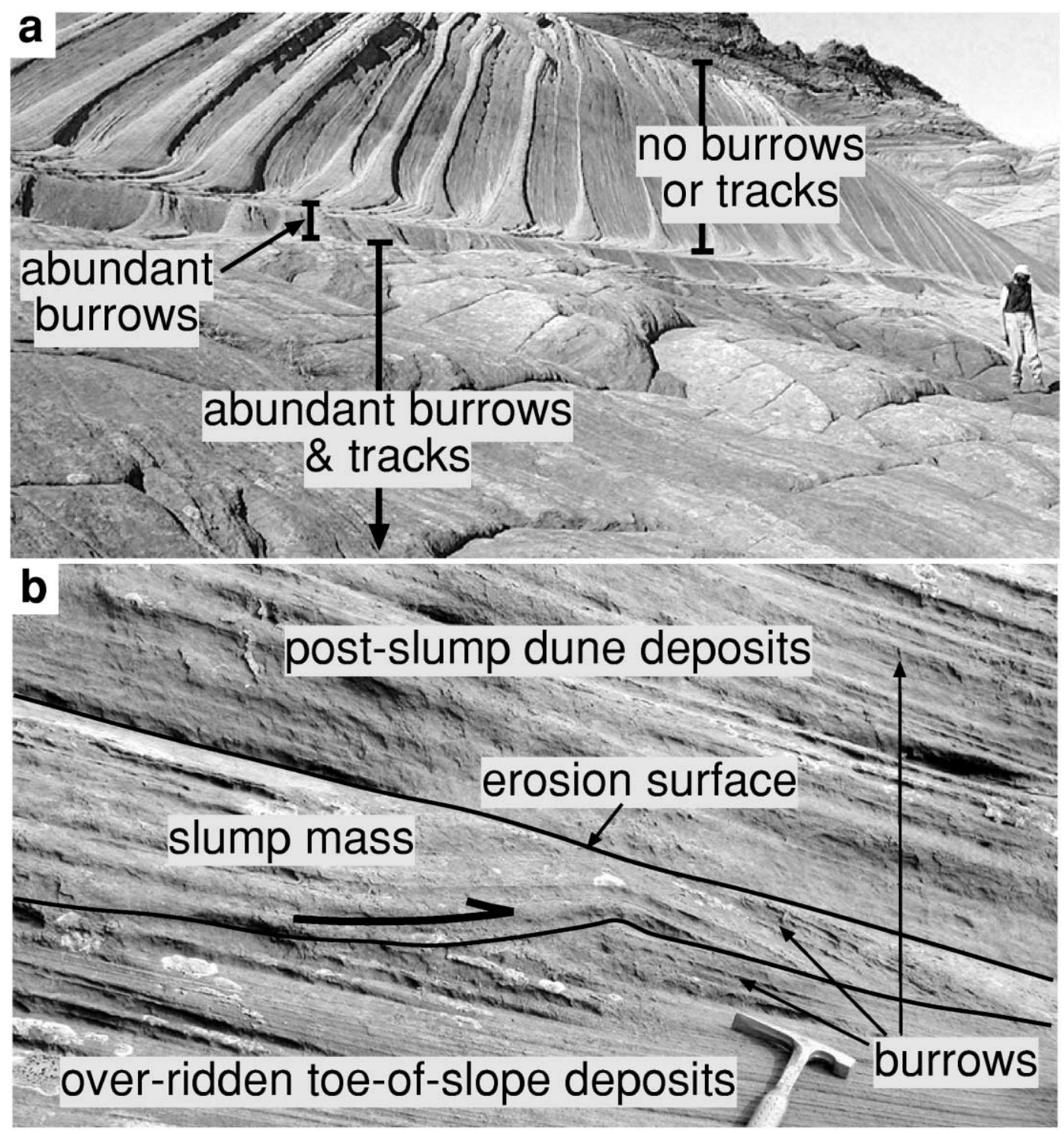

Figure 6. a, Annual depositional cycles (Hunter and Rubin 1983) of similar thickness in three sets of eolian crossstrata at Coyote Buttes (CB: fig. 1). Uppermost set displays cycles most prominently and is devoid of ichnofossils; cycles in the lower two sets are obscured by abundant trace fossils. $b$, Rainfall-generated slump mass in center lies above a detachment fault and is truncated by a wind-eroded surface. Burrows are abundant in both pre- and postslump strata. Burrow-free slump masses described by Loope et al. (2001) lie immediately above this set of cross-strata and were apparently emplaced after animal populations in the erg had collapsed (PH: fig. 1).

as first-order bounding surfaces rather than secondorder surfaces (which, in a compound dune, should dip in a downwind direction; figs. 4 and 12 in Brookfield 1977; fig. 7). Our firm conclusion is that the 60-m-thick interval between the wet interdune deposits was produced by the migration of numerous dunes and intervening flat interdunes (not by a single, giant, compound bedform) and that the bioturbated zones, accordingly, represent two distinct pluvial episodes (fig. 8). We interpret the limited lateral extent of zone 1 as the result of deflation after the water table fell at the end of the earlier pluvial episode. The absence of wet interdune deposits between some sets of bioturbated crossstrata suggests that wet interdune surfaces were laterally discontinuous in the direction perpendicular to dune migration (fig. 8).

The duration of the pluvial episodes represented 


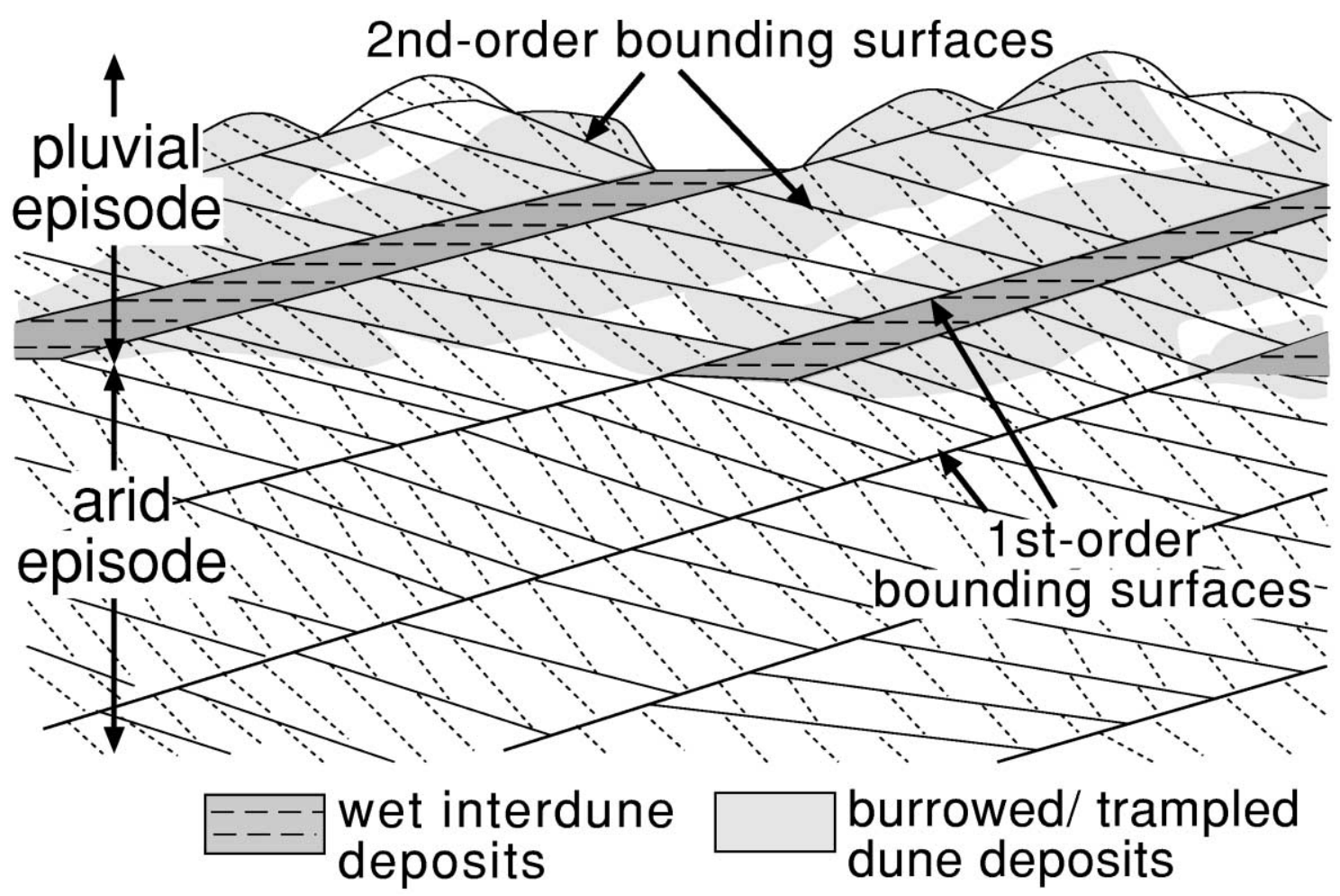

Figure 7. Rejected model for generation of superimposed zones of burrowed dune and interdune deposits. Wind direction is left to right. Lower portion of panel (arid interval) shows deposits of individual compound bedforms separated by first-order bounding surfaces generated during migration of dry interdunes. During pluvial episode, interdunes become depositional, and insect burrows and reptile tracks become widespread in adjacent cross-strata. Note dip of second-order bounding surfaces is in the downwind direction. This model assumes a single pluvial episode and is rejected because bioturbated zone 2 is much more laterally extensive than is zone 1 and because the bounding surfaces in the Navajo Sandstone that separate sets of cross-strata between the wet interdune deposits do not dip downwind (fig. 2) and cannot be interpreted as second-order bounding surfaces.

by the bioturbated zones cannot be accurately estimated at this time. The long-term vertical accretion and geologic preservation of eolian deposits are dependent on subsidence, but subsidence rates can give only a crude estimate of the amount of time represented by the bioturbated intervals. Allen et al. (2000; their fig. 1a) indicate that, in the study area, the entire Navajo Sandstone accumulated in about $5 \mathrm{~m}$.yr. This suggests that, on average, a 20$\mathrm{m}$-thick interval (including unconformities) would represent about 160,000 yr. Because the bioturbated intervals appear to be free of unconformities, we view this figure as an upper limit on the likely duration of the pluvial episodes. A lower limit of $4000-5000$ yr can be derived from a consideration of the number of sets of dune cross-strata present in a typical vertical section of the bioturbated zones (4 or 5 ), the dune migration rate (about $1 \mathrm{~m} / \mathrm{yr}$ ), and the likely wavelength of the dunes (about $1 \mathrm{~km}$ ).

During the Quaternary, rapid, large-magnitude changes in Africa's continental water cycle took place independent of the presence or absence of large polar ice sheets (Gasse 2000). Isotopic data from North African aquifers indicate intensive recharge during the Early to mid-Holocene and suggest a $500-\mathrm{km}$ enhancement of the northward seasonal migration of the intertropical convergence zone from its present summer position (Gasse 2000). The inferred Early Jurassic paleolatitude of the study area (about $17^{\circ} \mathrm{N}$; Peterson 1988) placed it in an analogous position to modern North Africa. Although prevailing arid conditions and an enormous supply of sediment led to the development of one of the largest sand seas known in Earth history, climate fluctuations, perhaps forced by orbital parameters and manifested by the northward expansion of the intertropical convergence zone, ensured at least two long-lived episodes of increased rainfall and intense biological activity during deposition of the Navajo Sandstone. 


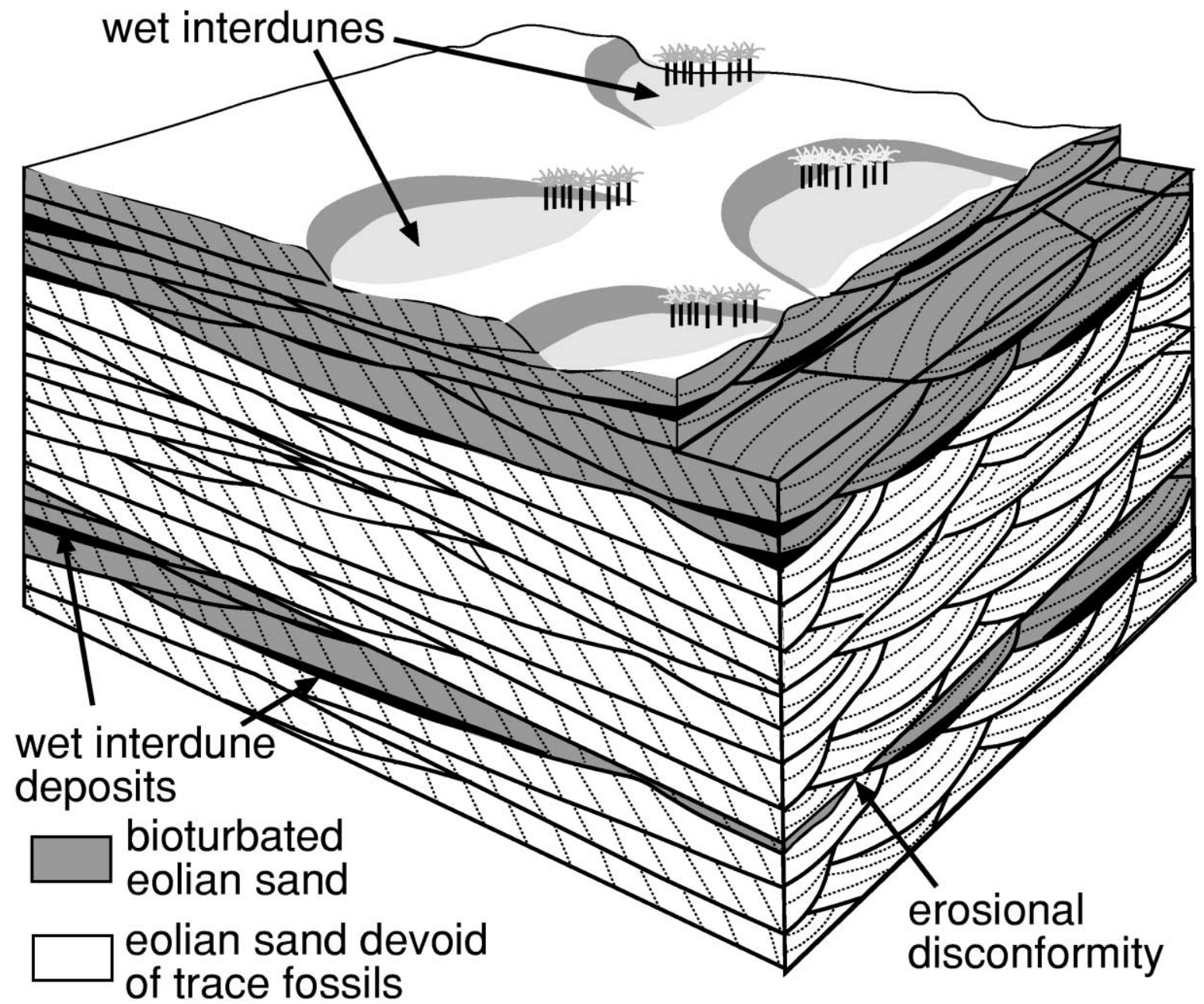

Figure 8. Preferred model for the accumulation of bioturbated and barren eolian cross-strata in the Navajo Sandstone. Wind is left to right. Each bioturbated zone is composed of the deposits of numerous dunes. The deposits of two temporally distinct pluvial intervals are separated by barren cross-strata that record the intervening arid interval. Deflation after a fall in the elevation of the water table generated an erosional disconformity at the top of the lower bioturbated zone.

\section{Conclusions}

The heavily bioturbated and trampled cross-strata within the Navajo Sandstone record two long-lived, monsoon-dominated pluvial episodes when the intertropical convergence zone encroached northward into a vast subtropical dune field. Plant life flourished in interdunes supplied with dilute fresh water from groundwater mounds beneath adjacent dunes. These dune and interdune strata record an ecological/depositional system without an obvious modern analog. Under Quaternary pluvial conditions in North Africa, modern plants were able to stabilize dunes, but in the Navajo Desert, dune migration and sediment aggradation continued unabated during pluvial periods. Although some un- known environmental conditions may have prevented dune stabilization, we consider it much more likely that, with the evolution of the angiosperms, the ability of land plants to stabilize dunes has improved greatly since the Early Jurassic.

\section{A C K N O W L E D G M E N T S}

The study area is administered by the U.S. Bureau of Land Management (BLM). The assistance of BLM workers B. Booker, B. Hammond, D. Powell, M. Salamacha, and A. Titus is greatly appreciated. This work was supported by the Schultz Chair of Stratigraphy at University of Nebraska and the National Science Foundation (EAR02-07893). We 
thank M. Blum, S. Fritz, J. Mason, and V. Zlotnik for helpful suggestions. Constructive comments by
D. Eberth and two anonymous reviewers greatly improved the article.

\section{R E F E R E N C E S C I T E D}

Ahlbrandt, T. S.; Andrews, S.; and Gwynne, D. T. 1978. Bioturbation in eolian deposits. J. Sediment. Petrol. 48:839-848.

Allen, P. A.; Verlander, J. E.; Burgess, P. M.; and Audet, D. M. 2000. Jurassic giant erg deposits, flexure of the United States continental interior, and timing of the onset of Cordilleran shortening. Geology 28:159-162.

Bromley, M. 1992. Topographic inversions of early interdune deposits, Navajo Sandstone (lower Jurassic), Colorado Plateau, U.S.A. Sediment. Geol. 80:1-25.

Brookfield, M. E. 1977. The origin of bounding surfaces in ancient aeolian sandstones. Sedimentology 24: 303-332.

Chan, M. A., and Archer, A. W. 1999. Spectral analysis of eolian foreset periodicities: implications for Jurassic decadal-scale paleoclimatic oscillators. Paleoclimates 3:239-255.

Curran, H. A., and White, B. 2001. Ichnology of Holocene carbonate eolianites of the Bahamas. In Abegg, F. E.; Harris, P. M.; and Loope, D. B., eds. Modern and ancient carbonate eolianites. SEPM Spec. Pub. 71:47-56.

Dincer, T.; Al-Mugrin, A.; and Zimmerman, U. 1974. Study of the infiltration and recharge through the sand dunes in arid zones with special reference to the stable isotopes and thermonuclear tritium. J. Hydrol. 23: 79-109.

Droser, M. L., and Bottjer, D. J. 1989. Ichnofabric of sandstones deposited in high-energy nearshore environments: measurement and utilization. Palaios 4: 598-604.

Evans, H. E. 1957. Comparative ethology of digger wasps of the genus Bembix. Ithaca, N.Y., Cornell University Press, $248 \mathrm{p}$.

. 1966. The comparative ethology and evolution of the sand wasps. Cambridge, Mass., Harvard University Press, $526 \mathrm{p}$.

Gasse, F. 2000. Hydrological changes in the African tropics since the last glacial maximum. Quat. Sci. Rev. 19:189-211.

Gilland, J. K. 1979. Paleoenvironment of a carbonate lens in the lower Navajo Sandstone near Moab, Utah. Utah Geol. 6:29-38.

Hasiotis, S. T. 1998. No bones about it ... it's continental ichnology! Palaios 13:1-2.

Hasiotis, S. T.; Dubiel, R. F.; and Demko, T. M. 1995. Bees, wasps, and insect nests predate angiosperms: implications for continental ecosystems and the evolution of social behavior. Rocky Mt. Sec., SEPM Newsletter 20:1.

Haynes, C. V. 1987. Holocene migration rates of the Sudano-Sahelian wetting front, Arba'in Desert, eastern Sahara. In Close, A. E., ed. Prehistory of arid North
Africa. Dallas, Southern Methodist University Press, p. 69-84.

Hunter, R. E., and Rubin, D. M. 1983. Interpreting cyclic crossbedding, with an example from the Navajo Sandstone. In Brookfied, M. E., and Ahlbrandt, T. S., eds. Eolian sediments and processes. Amsterdam, Elsevier, p. 429-454.

Kocurek, G., and Dott, R. H., Jr. 1983. Jurassic paleogeography and paleoclimate of the central and southern Rocky Mountains regions. In Reynolds, M. W., and Dolly, E. D., eds. Mesozoic paleogeography of the west-central United States. Denver, Rocky Mt. Sec., SEPM, p. 101-116.

Leonardi, G. 1981. Novo icnogenero de tetrapode mesozoico da Formacao Botucatu, Araraquara, SP. An. Acad. Bras. Cienc. 53:793-805.

Lockley, M., and Hunt, A. P. 1995. Dinosaur tracks and other fossil footprints of the western United States. New York, Columbia University Press, p. 129-150.

Loope, D. B.; Rowe, C. M.; and Joeckel, R. M. 2001. Annual monsoon rains recorded by Jurassic dunes. Nature 412:64-66.

Marzolf, J. E. 1983. Changing wind and hydrologic regime during deposition of the Navajo and Aztec Sandstones, Jurassic (?), southwestern United States. In Brookfield, M. E., and Ahlbrandt, T. S., eds. Eolian sediments and processes. Amsterdam, Elsevier, p. 635-660.

Peterson, F. 1988. Pennsylvanian to Jurassic eolian transportation systems in the western United States. In Kocurek, G., ed. Late Paleozoic to Mesozoic eolian deposits of the western interior of the United States. Sediment. Geol. 56:207-260.

Smith, R. M. H., and Mason, T. R. 1998. Sedimentary environments and trace fossils of Tertiary oasis deposits in the Central Namib Desert, Namibia. Palaios 13:547-559.

Sweeney, M. R., and Loope, D. B. 2001. Holocene dunesourced alluvial fans in the Nebraska Sand Hills. Geomorphology 38:31-46.

Talbot, M. R., and Williams, M. A. J. 1978. Erosion of fixed dunes in the Sahel, central Niger. Earth Surf. Proc. Landf. 3:107-113.

Toth, J. 1963. A theoretical analysis of groundwater flow in small drainage basins. J. Geophys. Res. 68: 4795-4812.

Winkler, D. A.; Jacobs, L. L.; Congleton, J. D.; and Downs, W. R. 1991. Life in a sand sea: biota from Jurassic interdunes. Geology 19:889-892.

Winter, T. C. 1976. Numerical simulation analysis of the interaction of lakes and groundwater. U.S. Geol. Surv. Prof. Pap. 1001, 45 p. 